\title{
若手会員の会 活動報告
}

http://wwwsoc.nii.ac.jp/jws/welnet/

(若手会員の会からのお知らせはホームページにも掲載しています)

\section{第 6 回溶接基礎セミナー開催報告}

若手会員の会運営委員会副委員長 川上博士（三重大学）

Report of the 6th Welding Basics Seminar

第 6 回溶接基礎セミナー・工場見学

「平成 19 年度溶接基礎セミナー」

主催 : ( 社) 溶接学会若手会員の会

( 社 ) 溶接学会東海支部

協賛 : (社) 日本溶接協会 三重県支部

\section{基礎セミナー}

開催日時: 平成 19 年 10 月 4 日（木） 10:00 16:30

開催場所 : 三重大学工学部大会議室

三重県津市栗真町屋 1577

参加者数 : 101 名

午前の部

司会 鈴木実平氏（三重大学）

10:00 10:10 開会の挨拶

東海支部支部長 沓名宗春氏

10:10 10:50 「アーク溶接」

田中 学氏 (大阪大学)

10:50 11:30「各種材料の溶接」

大縄登史男氏（(株）ダイヘン）

11:30 12:10 「レーザ溶接」

徐国建氏（名古屋大学）

午後の部

司会 川上博士氏（三重大学）

13:00 13:40 「固相接合」

13:40 14:20 「摩擦擋拌接合」

前田将克氏（大阪大学）

14:20 15:00「溶接治金学」

佐藤 裕氏（東北大学）

森 裕章氏（大阪大学）
15:00 15:40 「溶接継手強度の基礎」

大畑 充氏 (大阪大学)

15:40 16:20「溶接シミュレーション」

宮坂史和氏（大阪大学）

16:20 16:30＼cjkstart閉会の挨拶

若手会員の会委員長 佐藤 裕氏

\section{工場見学}

$$
\begin{gathered}
\text { 見学日時：平成 } 19 \text { 年 } 10 \text { 月 } 5 \text { 日（金） 9:00 15:00 } \\
\text { 見学場所：本田技研工業（株）鈴鹿製作所 } \\
\text { ユニバーサル造船（株）津事業所 } \\
\text { 参加者数：47名 }
\end{gathered}
$$

若手会員の会メンバーを講師としてお迎えし，溶接基 礎セミナーを東海支部と共催して三重県津市にて開催い たしました，本セミナーは，溶接・接合をこれから勉強 しょうという方，基本を知っておきたい方を対象に若手 会員の会が各地で開催するものです.

ここで，今回の開催地となりました津市について簡単 に紹介させていただきます. 北の四日市, 鈴鹿, 南の松阪, 伊勢の中間に位置する日本で一番短い地名で有名な県庁 所在地であります。北勢, 南勢との相対的関係から, オー ストラリアのキャンベラと似た状況にありますが，ネッ ト社会では「味噌かつ」,「天むす」,「たい焼き」,「いち ご大福」を世に送り出したとされています. 名古屋から 電車で 1 時間の距離にあり, 開催地として少々の不安が ありましたが，東海三県のみならず，関東からも参加い ただくことになり，セミナー，工場見学ともに盛況とな りました。 


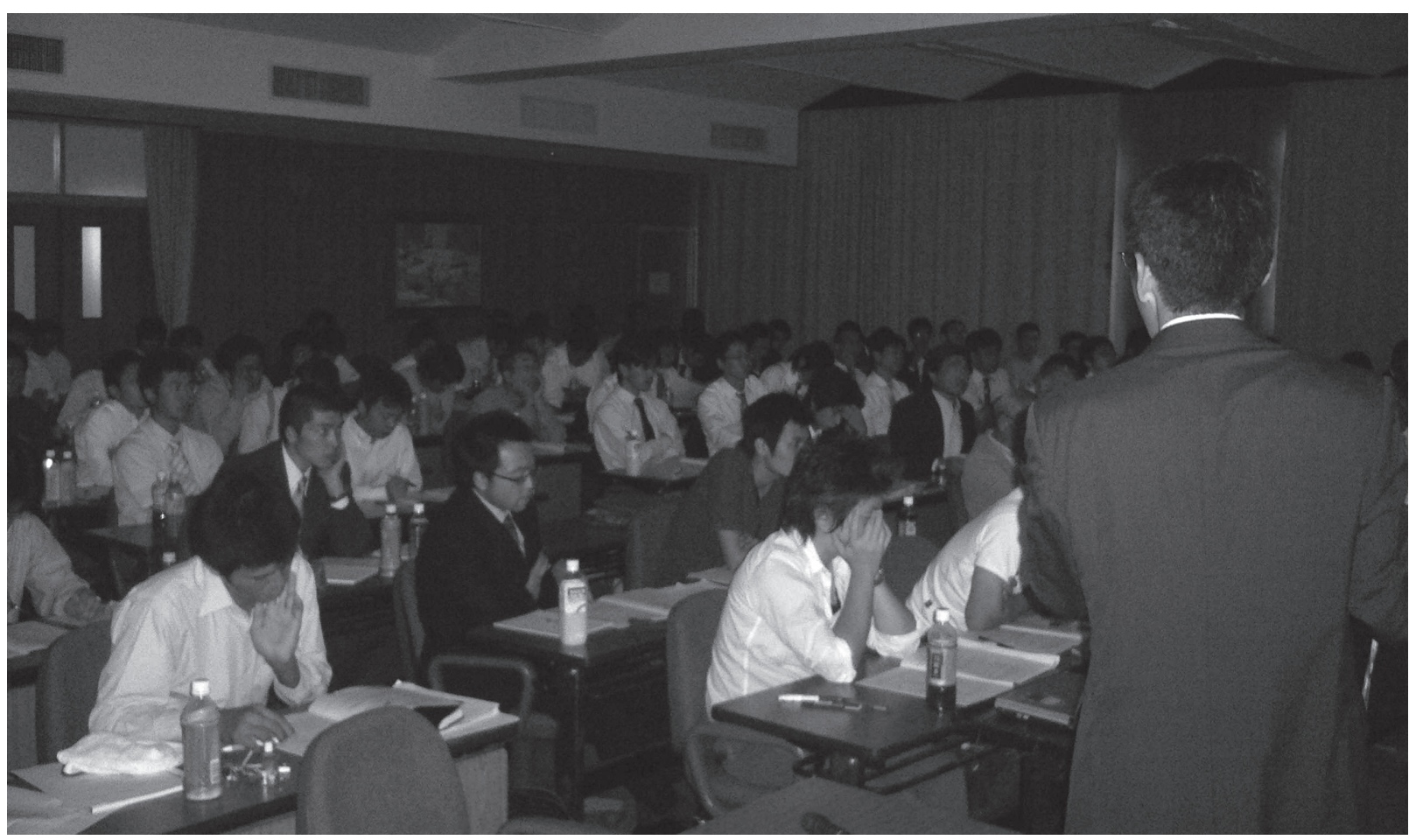

図 1 セミナーの様子

セミナーは,「アーク溶接」,「各種材料の溶接」,「レー ザ溶接」,「固相接合」,「摩擦擋拌接合」,「溶接治金学」,「溶 接継手強度の基礎」，「溶接シミュレーション」の 8 テー マについてご講演いただきました（図 1).

当日のアンケートによりますと, 参加者は $20 \sim 60$ 歳 代と幅広く, 基礎セミナーの主旨が多くの方に受け入れ られていることが分かりました。この内, 若手参加者 $(20$ 〜 30 歳代）は，約 70\% を占めておりました. 寄せられ たご要望・意見は具体的なものが多く, 今後の基礎セミ ナー開催にとって有益なものでありました。今回はテー マ数を欲張った結果, 講演時間が短くなり, 講師, 聴講 者の方々にとって不十分な面がありました, 次回担当す る機会があれば，改善したいと思っております。

翌日の工場見学は, 最初の見学先である本田技研工業 （株）鈴鹿製作所近くの近鉄白子駅に集合し，そこから 東海支部にて用意して頂いたバスにて移動しました。朝 9 時からの見学でしたが, すでに多くの小学生が社会見 学のために到着しておりました. 多数の見学者を受け入 れるため，とても整然とした見学コースが用意されてお り, 小学生グループに挟まれる形でガイドさんに引率さ れながら, 我々も見学させて頂きました. 少々, 童心に 戻った気分でした.

まず，エントランスホールにて人間型ロボット ASIMO の歓迎を受けました。スピーチの中で「思いや りのあるモノづくり」という言葉が今でも心に残ってい ます。概要説明の後, No. 1 ラインと TD ラインの見学 となりました。鈴鹿製作所では，シビック，フィット，
S2000 等の乗用車を生産しています．No. 1 ラインは自 動化ラインで，ロボットが各所に配置されており，見学 時はシビックが生産されておりました。検査工程では, 女性の方も活躍されていました。TD ラインは，S2000 用手作業組立ラインです。左手にNo. 1 ライン，右手に TD ラインを見ながら見学となりました。

次の見学先であるユニバーサル造船（株）津事業所で は，大型ばら積船，大型油槽船，液化ガス運搬船を建造 しています。隣接するJFE エンジニアリングとともに津 屈指の大事業所で，私自身は何回も大学の工場見学で訪 問しています。今回も多大なご配慮を頂き，惜しげなく 多数の溶接現場を見学させていただきました。また，偶 然にもドック内に入水する現場に立ち会うことができま した．バスを下車し，潮風に当たりながらしばらくその 様子を見ることができました。これは勤務されている方 でも，滅多にないとのことでした。見学後の多数の質問 に関しても，丁寧に対応していただきました。

\section{謝辞}

両日とも快晴に恵まれ，基礎セミナー，工場見学を盛 況のうちに，無事終了することができました。これも溶 接学会東海支部，日本溶接協会三重県支部，本田技研工 業（株）鈴鹿製作所様，ユニバーサル造船（株）津事業 所様，西手 尉雄様（本田技研工業），山崎 勲様，村山 宏様（ユニバーサル造船），北村 信男様（ジャパンテク ノメイト）のご厚意によるものと感謝しております. 